Jurnal Basicedu Volume 4 Nomor 2 April 2020 Hal.250- 256

JURNAL BASICEDU

Research \& Learning in Elementary Education

https://jbasic.org/index.php/basicedu

\title{
PENGARUH MEDIA GAMBAR TERHADAP HASIL BELAJAR IPA PADA SISWA SEKOLAH DASAR
}

\author{
Tarpan Suparman ${ }^{1}$, Anggy Giri Prawiyogi $^{2}$, Reni Endah Susanti ${ }^{3}$
}

Universitas Buana Perjuangan Karawang, Jawa Barat, Indonesia ${ }^{1,2,3}$

Email: tarpan.suparman@ ubpkarawang.ac.id ${ }^{\mathbf{1}}$, anggy.prawiyogi@ubpkarawang.ac.id 2, sd15.RENISUSANTI@mhs.ubpkarawang.ac.id ${ }^{\mathbf{3}}$

\begin{abstract}
Abstrak
Penelitian ini dilaksanakan di Gugus II Kecamatan Lemahabang, Kabupaten Karawang, dan penelitian di fokuskan pada siswa kelas V Tahun ajaran 2018/2019. Tujuan penelitian ini untuk mengetahui pengaruh media gambar terhadap hasil belajar IPA. Penelitian ini di latarbelakangi oleh rendahnya hasil belajar siswa terutama pada pelajaran IPA. Jenis Penelitian ini adalah penelitian semu (quasi eksperimen). Dengan Desain yang digunakan dalam penelitian adalah Pretest-Posttest Control Group Design. Populasi yang digunakan adalah SDN yang berada di Gugus II Kecamatan Lemahabang, yang terdiri dari 10 SD dan di fokuskan pada kelas V di Gugus II Kecamatan Lemahabang pada tahun 2018/2019, dengan sampel penelitian kelas V SDN Lemahabang III sebagai kelas eksperimen dan kelas V SDN Lemahabang V sebagai kelas kontrol. Intrumen tes yang digunakan untuk mengetahui hasil belajar IPA adalah dengan menggunakan tes berbentuk pilihan ganda. Hasil analisis data pada pretest kelas eksperimen nilai yang didapat masih rendah nilai yang diperoleh sebesar 24,00, sedangkan pada kelas kontrol adalah 25,83 . Setelah dilakukan treatment pembelajaran menggunakan media gambar, hasil analisis pada posttest kelas eksperimen diperoleh bahwa hasil belajar IPA meningkat dengan rata-rata 73,67, sedangkan pada kelas kontrol diperoleh nilai rata-rata 67,00. Berdasarkan uji t yang dilakukan diperoleh sig (2-tailed) $<0.05$ yang artinya terdapat perbedaan terhadap hasil belajar IPA. Dari hasil penelitian yang telah dilakukan dapat disimpulkan bahwa terdapat perbedaan pengaruh media gambar terhadap hasil belajar IPA pada siswa kelas V di Sekolah Dasar pada tahun pelajaran 2018/2019.
\end{abstract}

Kata Kunci : Media Gambar, Hasil Belajar IPA

\begin{abstract}
This reseach was conducted ithn Cluster II, Lemahabang District, Karawang Regency, and the research was focused on fifth grade students in the 2018/2019 academic year. The purpose of this study was to determine the effect of media iamges on science learning outcomes. This research is motivated by the low student learning outcomes, especially inscience lesson. This type of research is quasi-research (quasi-experimental). The design used in this study is PretestPosttets Control Group Design. The population used is the SDN located in Cluster II Lemahabang District, which consist of 10 elementary school and is focused on class V in Cluster II in Lemahabang District in 2018/2019, with a sample study of class V of Lemahabang III SDN as an experimental class and class V SDN Lemahabang V as control class. The test isntrument used to determine the learning outcomes of science is to use multiple choice test. The result of data analysis in the experimental class pretest the value obtained is still low value obtained by 24,00, while in the control class is 25,83. After treatment of learning using image media, the result of the analysis in the experimental class posttest obtained that science learning outcomes increased by an average of 73,67, while the control class obtained an average value of 67,00. Based on the t test performed sig (2-tailed) $<0,05$ which means that there are differences in science learning outcomes. From the result of the research that has been done it can be concluded that there are differences in the effect of media images on the learning outcomes on Natural Sciences in fifth grade student in elementary school in the 2018/2019 school year
\end{abstract}

Keywords: Image media, science learning outcomes

@ Jurnal Basicedu Prodi PGSD FIP UPTT 2020

$\triangle$ Corresponding author :

Address : -

Email :-

ISSN 2580-3735 (Media Cetak)

Phone :ISSN 2580-1147 (Media Online) 
251 Pengaruh media gambar terhadap hasil belajar IPA pada siswa sekolah dasar - Tarpan Suparman, Anggy Giri Prawiyogi, Reni Endah Susanti

\section{PENDAHULUAN}

Pembelajaran merupakan gabungan dari beberapa komponen dalam belajar yang mencakupi guru, siswa, sarana dan prasarana serta lingkungan belajar, semua komponen itu penting untuk berlangsungnya keberhasilan dalam pembelajaran. Dalam pembelajaran juga tentu banyak sekali yang di pelajari, salah satunya pelajaran yang di pelajari adalah tentang Ilmu Pengetahuan Alam (IPA).

Ilmu Pengetahuan Alam (IPA) adalah Ilmu yang mengatur seluk beluk makhluk hidup seperti habitatnya, perkembangbiakannya, dll. Setelah mengetahui tentang IPA, maka terjadilah proses pembelajaran IPA. Namun pada kenyataannya di lapangan, hasil belajar siswa pada pelajaran Ilmu Pengetahuan Alam (IPA) masih rendah dan kurang memuaskan, seperti hasil studi awal penelitian di SDN Lemahabang III, peneliti mengamati siswa kelas V. Ada permasalahan yang di temukan peneliti di antaranya: (1) Rendahnya hasil belajar IPA di kelas V Sekolah Dasar diketahui dari nilai hasil ulangan siswa masih di bawah KKM, (2) Pembelajaran secara umum masih menggunakan pembelajaran konvensinal artinya dalam menyampaikan materi pembelajaran guru masih menggunakan metode ceramah (hanya menyampaikan materi tanpa adanya media), (3) Dalam proses belajar siswa di kelas siswa kurang antusias, (4) Siswa kurang aktif dan tidak banyak bertanya kepada guru, (5) Proses pembelajaran sekolah belum kondusif, (6) Belum digunakannya media pembelajaran pada proses pembelajaran, (7) Pembelajaran menggunakan media gambar terhadap hasil belajar IPA.

Dari hasil studi awal penelitian tersebut, diketahui bahwa pada kenyataannya dengan hanya menggunakan pembelajaran konvensional (ceramah), pembelajaran jadi kurang efektif dan menjadi kurang minatnya siswa pada pelajaran
IPA, dan pada akhirnya hasil belajar siswa pun kurang memuaskan. Salah satu solusinya agar pembelajaran lebih efektif, minat belajar siswa pun bertambah apalagi dalam pembalajaran IPA, serta hasil belajar siswa pun bisa memuaskan harus di gunakannya media pembelajaran seperti media gambar.

IPA adalah rumpun ilmu, memiliki karakteristik khusus yaitu mempelajari fenomena alam yang faktual (factual), baik berupa kenyataan (reality) atau kejadian (event) dan hubungan sebab-akibatnya. Ilmu Pengetahuan Alam (IPA) adalah usaha manusia dalam memahami alam semesta melalui pengamatan tepat sasaran, yang memiliki karakteristik khusus, dan berbagaifenomena/perilaku/karakteristik yang dikemas menjadi sekumpulan teori (Yuliana, 2016).

Tujuan pembelajaran IPA sebagaimana termaktub dalam Bloom (Trianto, 2014) bahwa: Diharapkan dapat memberikan pengetahuan (kognitif), yang merupakan tujuan utama dari pembelajaran. Jenis pengetahuan yang dimaksud adalah pengetahuan dasar dari prinsip dan konsep yang bermanfaat untuk kehidupan sehari-hari. Pengetahuan secara garis besar tentang fakta yang ada di alam untuk dapat memahami dan memperdalam lebih lanjut, dan melihat adanya keterangan serta keteraturannya. Disamping hal itu Pembelajaran sains diharapkan pula memberikan keterampilan (psikomotorik), kemampuan sikap ilmiah (afektif), pemahaman, kebiasaan, dan apresiasi. Di dalam mencari jawaban terhadap suatu permasalahan. Karena ciri-ciri tersebut yang membedakan dengan pembelajaran lainnya.

Hasil belajar IPA adalah hasil yang diperoleh dan dicapai siswa setelah belajar pengetahuan tentang mata pelajaran IPA yang bukan hanya sekedar mengandalkan daya 
252 Pengaruh media gambar terhadap hasil belajar IPA pada siswa sekolah dasar - Tarpan Suparman, Anggy Giri Prawiyogi, Reni Endah Susanti

mengingat melainkan lebih dari itu seperti dengan menggunakan media mencatat untuk menunjang hasil belajar dengan menjadi lebih baik. Dengan indikator: mengingat, memahami, mengaplikasikan, menganalisis. Untuk mencapai indikator yang diharapkan guru harus pintar memilih media dalam pembelajaran. Salah satu media pembalajaran yang dapat di gunakan dalam mengatasi masalah yang timbul selama proses pembelajaran adalah dengan media gambar. Dengan media gambar, siswa diharapkan mampu mengikuti pelajaran dengan fokus dan menyenangkan. Sehingga pelajaran apapun yang disampaikan oleh guru kepada siswa dapat di ingat dan terima dengan baik.

$$
\text { Media gambar adalah media yang }
$$
mengkombinasikan fakta dan gagasan secara jelas dan kuat melalui kombinasi pengungkapan katakata dengan gambar-gambar (Rohini, 2010). Gambar termasuk ke dalam media visual. Media ini berfungsi untuk menyalurkan pesan dari penerima sumber ke penerima pesan (Haryanti, 2018).

Gambar adalah media pengajaran yang amat dikenal di dalam setiap kegiatan pengajaran dan yang paling umum dipakai yang berfungsi untuk menyalurkan pesan dari penerima sumber ke penerima pesan. Media gambar adalah media yang sederhana dua dimensi pada bidang yang tidak transparan dan dapat dikembangkan dalam berbagai bentuk melalui kombinasi pengungkapan kata-kata dengan gambar-gambar.

Media gambar mempunyai kelebihan dan kelemahan dalam pembelajaran (Sadiman, 2014), yaitu:

1. Gambar sifatnya konkret.

2. Gambar dapat mengatasi batasan ruang dan waktu.

3. Gambar dapat mengatasi keterbatasan pengamatan kita.
4. Gambar dapat memperjelas suatu masalah, dalam bidang apa saja untuk tingkat usia berapa saja, sehingga dapat mencegah atau membetulkan kesalahpahaman.

5. Gambar harganya murah dan gampang didapat serta digunakan tanpa memerlukan peralatan khusus.

6. Gambar hanya menekankan persepsi indera penglihatan.

7. Gambar merupakan benda yang terlalu kompleks.

8. Ukuran sangat terbatas untuk kelompok besar

\section{METODE PENELITIAN}

Metode penelitian yang akan digunakan ialah metode penelitian eksperimen semu (quasi eksperiment). Desain yang digunakan dalam penelitian ini ialah Pretest-Posttest Control Group Design. Dalam design ini terdapat dua kelompok yang dipilih secara random, kemudian diberi pretest untuk mengetahui keadaan awal adakah perbedaan antara kelompok eksperimen dan kelompok kontrol (Sugiyono, 2017). Adapun desain penelitian ini adalah sebagai berikut:

Tabel 1

Desain Penelitian

\begin{tabular}{|l|l|l|l|l|}
\hline No & $\begin{array}{l}\text { Kelas } \\
\text { Penelitian }\end{array}$ & Pretest & Treatment & Posttest \\
\hline 1 & $\begin{array}{l}\text { Kelas } \\
\text { Eksperimen }\end{array}$ & $\mathrm{O}_{1}$ & $\mathrm{X}$ & $\mathrm{O}_{2}$ \\
\hline 2 & $\begin{array}{l}\text { Kelas } \\
\text { Kontrol }\end{array}$ & $\mathrm{O}_{3}$ & - & $\mathrm{O}_{4}$ \\
\hline
\end{tabular}

Keterangan:

$\begin{array}{ll}\mathrm{KE} & : \text { Kelompok Eksperimen } \\ \mathrm{KO} & \text { : Kelompok Kontrol } \\ \mathrm{O}_{1} & \text { : Pretest Kelompok } \\ & \text { Eksperimen } \\ \mathrm{O}_{2} & \text { : Posttest } \text { Kelompok } \\ & \text { Eksperimen } \\ \mathrm{O}_{3} & : \text { Pretest Kelompok Kontrol } \\ \mathrm{O}_{4} & \text { Posttest Kelompok Kontrol } \\ \mathrm{X} & : \text { Perlakuan pada kelompok eksperimen } \\ \text { yang } & \text { menggunakan media gambar dalam } \\ \text { pembelajaran } & \end{array}$


253 Pengaruh media gambar terhadap hasil belajar IPA pada siswa sekolah dasar - Tarpan Suparman, Anggy Giri Prawiyogi, Reni Endah Susanti

Tempat penelitian ini dilakukan di Gugus II Kecamatan Lemahabang, Kabupaten Karawang, dan penelitian ini di fokuskan pada siswa kelas V. Waktu yang digunakan dalam penelitian ini yaitu pada semester genap tahun ajaran 2018/2019, dan di laksanakan pada bulan Januari sampai dengan Juli.

Teknik pengumpulan data yang digunakan dalam penelitian ini adalah tes. Tes digunakan untuk mengukur hasil belajar IPA di awal dan diakhir pada kelas yang diberi perlakuan dengan media gambar yang berupa soal pilihan ganda, yang akan diganakan pada pretest dan posttest. Tes awal (pretest) dilakukan sebelum diberikan perlakuan, dan tes akhir (posttest) dilakukan setelah diberikan perlakuan untuk mengukur hasil belajar IPA pada materi struktur bumi. Setelah diadakan pretest dan posttest kemudian hasil kedua tes tersebut dibandingkan. Apakah ada perbedaan sebelum dan sesudah diberi perlakuan.

Uji Validitas Penelitian. Validitas adalah sebuah standar yang memperlihatkan kategori kesasihan sebuah instrumen. Instrumen disebut valid bila mampu menghitung sesuatu yang ingin dicapai dan sesuai dengan kriteria tertentu (Arikunto, 2013).

Setelah instrumen disusun, selanjutnya ialah melaksanakan uji validitas dan reliabilitas soal. Uji coba instrumen penelitian dilakukan pada 30 siswa kelas V SDN Lemahmukti 1. Berdasarkan hasil validasi terhadap 30 butir soal yang diuji cobakan menunjukan terdapat 20 butir soal yang terhitung valid $\left(\mathrm{r}_{\text {hitung }}>0,361\right)$, dan terdapat 10 butir soal yang terhitung tidak valid $\left(\mathrm{r}_{\text {hitung }}<0,361\right)$. Kriteria butir soal validitas tes tersebut yang akan digunakan untuk mengambil data yang akan mengukur hasil belajar IPA sehingga interpretasi validitas termasuk dengan kategori baik.

Reliabilitas adalah sesuatu instrumen cukup dapat dipercaya untuk digunakan sebagai alat pengumpul data karena instrumen tersebut sudah baik. Suatu tes dapat dikatakan mempunyai taraf kepercayaan yang tinggi apabila tes tersebut dapat memberikan hasil yang tetap (Arikunto, 2010). Berdasarkan hasil perhitungan uji reliabilitas 20 butir soal yang valid diperoleh nilai $r_{11}=0,87$. Nilai $r_{11}$ selanjutnya di bandingkan dengan $r_{11}>r_{\text {tabel. }}$ Sehingga instrumen tes dapat dikatakan reliabel dengan interpretasi reliabilitas

Daya pembeda soal adalah kemampuan soal untuk membedakan antar siswa yang pandai (berkemampuan tinggi) dengan siswa yang berkemampuan rendah. Perhitungan daya pembeda diperoleh 20 butir soal yang valid (Arikunto, 2017)

Menurut Arikunto (2017:222) soal yang baik adalah soal yang tidak terlalu mudah atau tidak terlalu sukar. Bilangan yang menunjukan sukar mudahnya sesuatu soal disebut indeks kesukaran (difficulty index). Besarnya indeks kesukaran antara 0,00 sampai dengan 1,0 indeks kesukaran ini menunjukan taraf kesukaran soal. Soal dengan indeks kesukaran 0,0 menunjukan bahwa soal itu terlalu sukar, sebaliknya indeks 1,0 menunjukan bahwa soal itu terlalu mudah. Perhitungan tingkat kesukaran di peroleh 20 butir soal yang valid.

Teknik analisis data yang digunakan dalam penelitian ini adalah :

Uji normalitas dilakukan untuk mengetahui apakah sampel yang diteliti berasal dari populasi yang terdistribusi normal atau tidak. Dalam uji normalitas penelitian ini menggunakan perhitungan dengan SPSS 23.0 for windows memiliki tingkat keakuratan yang lebih kuat jika banyaknya data atau sampel yang dianalisis kurang dari $50 \quad(\mathrm{n}<50)$. Uji normalitas dilakukan pada pretest dan posttest dari masing-masing kelompok kelas eksperimen dan kelompok kelas kontrol. Hipotesis yang digunakan adalah sebagai berikut:

$\mathrm{H}_{\mathrm{O}} \quad$ : Data berdistribusi normal, jika nilai sig < 0,05 maka $\mathrm{H}_{\mathrm{O}}$ ditolak 
254 Pengaruh media gambar terhadap hasil belajar IPA pada siswa sekolah dasar - Tarpan Suparman, Anggy Giri Prawiyogi, Reni Endah Susanti

$\mathrm{H}_{\mathrm{a}} \quad$ : Data tidak berdistribusi normal, jika nilai $\operatorname{sig} \geq 0,05$ maka $\mathrm{H}_{\mathrm{a}}$ diterima

Uji homogenitas dilakukan untuk menilai yang homogenitas atau perbedaan varians antara kedua kelompok atau lebih. Pada penelitian ini dilakukan perhitungan uji levene's test dengan menggunakan SPSS 23.0 for windows. Hipotesis yang digunakan adalah sebagai berikut:

$\mathrm{H}_{\mathrm{O}}$ : Kelas Eksperimen dan Kelas

Kontrol memiliki varians yang sama (homogen)

$\mathrm{H}_{\mathrm{a}}$ : Kelas Eksperimen dan Kelas

Kontrol tidak memiliki varians

yang sama (tidak homogen)

Uji statistik yang digunakan adalah shapiro-wilk dengan menggunakan SPSS 23.0 for windows dengan kriteria uji adalah sebagai berikut:

1) Jika nilai $\operatorname{sig}<\alpha(\alpha=0,05)$ maka $\mathrm{H}_{\mathrm{O}}$ ditolak

2) Jika nilai $\operatorname{sig} \geq \alpha(\alpha=0,05)$ maka $\mathrm{H}_{\mathrm{O}}$ diterima

1. N-Gain

Tabel 2

Kriteria Pengaruh Nilai Gain

\begin{tabular}{|c|l|c|}
\hline No & $\begin{array}{c}\text { Nilai Gain } \\
\text { Ternormalisasi }\end{array}$ & Interpretasi \\
\hline 1 & $-1.00 \leq \mathrm{g}<0.00$ & $\begin{array}{c}\text { Terjadi } \\
\text { penurunan }\end{array}$ \\
\hline 2 & $\mathrm{~g}=0.00$ & Stabil \\
\hline 3 & $0.00<\mathrm{g}<0.30$ & Rendah \\
\hline 4 & $0.30<\mathrm{g}<0.70$ & Sedang \\
\hline 5 & $0.70<\mathrm{g}<1.00$ & Tinggi \\
\hline \multicolumn{2}{|c|}{ Sumber $:$ Hake, sebagaimana dikutip } \\
\hline
\end{tabular}

dalam (Sundayana, 2016).

Dilihat dari rata-rata nilai gain kelas eksperimen diperoleh hasil 0.65 dan termasuk ke dalam kriteria sedang, dan Dilihat dari rata-rata nilai gain kelas kontrol diperoleh hasil 0.55 dan termasuk ke dalam kriteria sedang.
Tabel 3

Uji-t Nilai Gain Hasil Belajar IPA

\begin{tabular}{|c|c|c|c|}
\hline No & $\begin{array}{c}\text { Nilai } \\
\text { sig }\end{array}$ & $\begin{array}{c}\text { Taraf } \\
\text { signifikan }\end{array}$ & Kesimpulan \\
\hline 1 & 0.011 & 0.05 & Ho ditolak \\
\hline \multicolumn{3}{|c|}{ Dilihat pada tabel, nilai signifikansi } \\
\hline
\end{tabular}

tailed) sebesar 0,011. Untuk pengujian perbedaan rata-rata nilai akhir hasil belajar IPA siswa yaitu dua pihak, karena nilai sig 0,05 maka $\mathrm{H}_{\mathrm{O}}$ ditolak artinya terdapat perbedaan nilai akhir kemampuan hasil belajar IPA yang menggunakan media gambar dengan yang tidak menggunakan media gambar/konvensional

\section{HASIL DAN PEMBAHASAN}

Pada hasil uji pretest dapat dilihat kelas eksperimen dengan nilai rata-rata 24.00, nilai tertinggi yaitu 50, dan nilai terendah yaitu 10, dan setelah melakukan uji posttest dengan menggunakan media gambar mendapatkan hasil dengan nilai rata-rata 73.67 , nilai tertinggi yaitu 95, dan nilai terendah yaitu 50. Sedangkan hasil uji pretest kelas kontrol dengan nilai rata-rata 25.83, nilai tertinggi yaitu 55, dan nilai terendah yaitu 0 , dan setelah melakukan uji posttest dengan tidak menggunakan media gambar mendapatkan hasil dengan nilai rata-rata 67.00, nilai tertinggi yaitu 90, dan nilai terendah yaitu 45. Jadi dapat dikatakan bahwa nilai kelas eksperimen lebih besar daripada nilai kelas kontrol

Pada saat penelitian di kelas kontrol, siswa kurang aktif dan kurang antusias dibanding siswa di kelas eksperimen. Pada saat pembelajaran dikelas kontrol siswa terlihat bosan saat guru menyampaikan materi yang menyebabkan siswa mendapat nilai rendah karena kurang fokus memperhatikan guru saat menjelaskan materi. Namun, pada saat menggunakan media gambar pada kelas eksperimen dapat dilihat bahwa siswa sangat aktif dan antusias saat pembelajaran, sehingga hasil belajar IPA menjadi meningkat. 
255 Pengaruh media gambar terhadap hasil belajar IPA pada siswa sekolah dasar - Tarpan Suparman, Anggy Giri Prawiyogi, Reni Endah Susanti

Dalam uji hipotesis nilai sig 2-tailed $=0.011$ yaitu $<0.05$ yang berarti media gambar berpengaruh untuk meningkatkan hasil belajar IPA pada siswa kelas V di Sekolah Dasar.

\section{SIMPULAN}

Berdasarkan hasil penelitian yang telah dilakukan dapat disimpulkan bahwa penelitian ini menggunakan metode eksperimen semu (quasi eksperiment). Desain yang digunakan dalam penelitian ini ialah Pretest-Posttest Control Group Design. dan dalam penelitian ini terdapat perbedaan pengaruh yang signifikan mengenai hasil belajar IPA antara kelas eksperimen yang diberi perlakuan dengan media gambar dan kelas kontrol yang tidak diberi perlakuan dengan media gambar/konvensional. Penelitian ini dilakukan di SDN Lemahabang III dan SDN Lemahabang V, Kecamatan Lemahabang, Kabupaten Karawang pada materi struktur bumi kelas $\mathrm{V}$ tahun ajaran 2018/2019 dengan hasil pengujian menggunakan uji-t 2-tailed 0,011 yaitu $<0,05$ sehingga $\mathrm{H}_{\mathrm{O}}$ ditolak yang berarti terdapat perbedaan hasil belajar IPA pada siswa kelas V yang menggunakan media gambar dengan yang tidak menggunakan media gambar/konvensional.

Berdasarkan kesimpulan dan hasil penelitian yang diperoleh saat di lapangan maka peneliti dapat memberikan saran sebagai berikut:

1. Berdasarkan dari kesimpulan hasil penelitian yang menunjukkan bahwa pembelajaran dengan menggunakan media gambar mengalami perbedaan yang signifikan. Oleh karena itu, disarankan pembelajaran menggunakan media gambar.

2. Kelemahan siswa dalam hasil belajar IPA dapat diminimalisir dengan media gambar yaitu guru bisa memperlihatkan struktur bumi sehingga siswa dapat melihat secara konkret gambar dari struktur bumi.
3. Bagi peneliti selanjutnya, hasil penelitian ini dapat dijadikan sebagai salah satu sumber informasi dan hendaknya peneliti ini dapat dilengkapi dengan meneliti aspek-aspek lain secara terperinci yang belum terjangkau oleh peneliti lainnya. Penelitian ini dapat pula dijadikan sebagai tolak ukur untuk penelitian yang berhubungan dengan hasil belajar IPA ataupun media gambar.

\section{DAFTAR PUSTAKA}

Arikunto, S. (2010). Prosedur Penelitian Suatu Pendekatan Praktik. Rineka Cipta.

Arikunto, S. (2013). Prosedur Penelitian Suatu Pendekatan Praktik. Rineka Cipta.

Arikunto, S. (2017). Prosedur Penelitian Suatu Pendekatan Praktik. Rineka Cipta.

Haryanti, A. S. (2018). Penggunaan Media Gambar Dan Media Radio Pada Pembelajaran Menulis Deskripsi Siswa Kelas X Sma Tunas Harapan Balaraja-Tangerang. Jurnal Kredo, 1(14-25).

Rohini. (2010). Pengaruh Penggunaan Media Gambar Terhadap Hasil Belajar Ilmu Pengetahuan Sosial Siswa Kelas Iv Sdn 02 Korleko. Jurnal Education, 5(2), 75-90.

Sadiman, A. (2014). Media pendidikan pengertian pengembangan dan pemanfaatannya. Pustekkom Dikbud dan PT. Raja Grafindo Persada.

Sugiyono. (2017). Metode Penelitian Kuantitatif Kualitatif dan R\&D. Alfabeta.

Sundayana, R. (2016). Kaitan Antara Gaya

Belajar, Kemandirian Belajar, dan

Kemampuan Pemecahan Masalah Siswa

SMP dalam Pelajaran Matematika. Jurnal

Ilmiah, 8(1), 31-40.

Trianto. (2014). Model Pembelajaran Terpadu: 
256 Pengaruh media gambar terhadap hasil belajar IPA pada siswa sekolah dasar - Tarpan Suparman, Anggy Giri Prawiyogi, Reni Endah Susanti

Konsep, Strategi, dan Implementasinya dalam Kurikulum Tingkat Satuan Pendidikan (KTSP). Bumi Aksara.

Yuliana, F. E. (2016). Keefektifan Model Picture And Picture Terhadap Hasil Belajar Ipa Materi Perubahan Lingkungan Fisik Siswa Kelas Iv Sdn Gugus Plangkawati Semarang.

Universitas Negeri Semarang. 